\title{
Spiny Hopsage Germination
}

\section{KARL WOOD, ROBERT W. KNIGHT, AND JAMES A. YOUNG}

Highlight: Germination of spiny hopsage seeds was studied in relation to constant and alternating temperatures and moisture stress. Seeds germinated and developed rapidly with $70 \%$ germination at optimum temperatures in 1 week. Optimum germination after 2 weeks of incubation occurred with $5^{\circ} \mathrm{C}$ nights and 10 to $30^{\circ} \mathrm{C}$ days. The rapid germination permitted growth on soils that were dried from field capacity to low matric potentials. One seed source from Mojave, California, had unusually high germination at low osmotic potentials in solutions of polyethylene glycol. Nominal seedling establishment occurred when bracted seeds were broadcast on loose seedbeds. Seedlings were not established when threshed or bracted seeds were broadcast on compacted soils.

Spiny hopsage (Grayia spinosa) is unique in the ecology of the Great Basin. It is one of the few woody species found in plant communities of both the sagebrush (Artemisia) and shadscale (Atriplex confertifolia) zones (Billings, 1949). Most importantly, it is the only highly preferred browse species in many low-elevation big-sagebrush (Artemisia tridentata) communities (Dayton, 1931). As a valuable browse species, spiny hopsage offers the potential for revegetating degraded rangelands or wildfire areas. To use this species or any other native shrub for revegetation, we must know the inherent germination requirements of the seeds and the microenvironmental characteristics of a seedbed that enables the seeds to germinate (Springfield, 1970).

Our objectives were to study the germination of seeds (achenes) of spiny hopsage in relation to temperature and osmotic and matric potentials.

The authors are graduate research assis tants, University of Nevada, Reno and Oregon State University, respectively, and range scientist, Agricultural Research Service, U.S. Department of Agriculture, Reno, Nevada 89502 .

The work represents cooperative investigation of the Western Region, Agr. Res. Serv., U.S. Dep. Agr., and the Agricultural Experiment Station, Univ. of Nevada, Reno (Journal Series No. 295).

The authors acknowledge the assistance of Richard L. Everett, range conservation ist, Intermountain Forest and Range Experiment Station, Reno, Nev.; and B. L. Kay, wildland seeding specialist, University of Calivornia, Davis, for providing seeds of spiny hopsage and helpful comments.

Manuscript received December 19, 1974. tic boxes with $5 \mathrm{~g}$ of ground polystyrene plastic and $100 \mathrm{ml}$ of solution (Young et al., 1968). Seeds were incubated at $15^{\circ} \mathrm{C}$ and the number and length of germinating seedlings were determined after 1 week.

\section{Soil Matric Potential}

A 15-bar ceramic plate soil moisture extractor was used to obtain matric potentials of $-2,-4,-6,-8$, $-10,-12$, and -15 bars, following the procedures of Young et al. (1970). The extractor was operated in a germinator maintained at $15^{\circ} \mathrm{C}$. Clay, loam, and fine sand were used as germination substrates. Both wet and dry cycles were used. Wet cycles consisted of planting the seeds in soil and bringing the soil to the desired matric potential in the extractor. In the dry cycle, the soil was brought to the desired matric potential; then the seeds were planted, and the plates were returned to the extractor.

\section{Establishment of Seedlings in Relation} to Soil Microtopography

Cups, $15 \mathrm{~cm}$ in diameter, were filled with sandy loam soil. In one experiment, the soil was left undisturbed after being poured into the cups; in another experiment, the soil surface was smoothed after we filled the cups. Spiny hopsage seeds were broadcast on the surface of the soil or covered with $0.5 \mathrm{~cm}$ of soil. Both bracted and free seeds were used. The cups were placed in the greenhouse, and established seedlings were counted after 1 week.

\section{Hydroscopic Nature of Bracts}

We placed $1 \mathrm{~g}$ of air-dry spiny hopsage bracts with seeds in a desiccator in which a $10 \%$ relative humidity was maintained with $\mathrm{LiCl}$. After 24 hours, the samples were reweighed and placed in desiccators in which a saturated relative humidity was maintained. The weight 24 hours later was obtained for calculating moisture absorption. Four replications were used.

\section{Results}

lures were used because of a supply of seed.

\section{Osmotic Potential}

Aqueous solutions with osmotic potentials of $-4,-6,-8,-12$, and -16 bars were prepared by dissolving appropriate amounts of polyethylene glycol (mol wt $=1,540)$ in distilled water. A similar range of potentials, $-4,-8,-13,-17$, and -22 bars, was prepared with $\mathrm{NaCl}$. Osmotic pressures of solutions were checked with a vapor pressure osmometer, and concentrations were adjusted within 0.1 bar. We placed 25 spiny hopsage seeds in plas-
The seeds of spiny hopsage, less than $2 \mathrm{~mm}$ long, are composed of an embryonic seedling tightly coiled within a very thin pericarp. The seeds are enclosed in two conduplicate bracts that are united at their edges to form a slightly inflated sack about $1 \mathrm{~cm}$ in diameter. The seeds normally do not dehisce from the bracts, but the few lots of seeds that enter into the seed trade and are available for revegetation often are threshed from the bract to reduce storage space and shipping cost. 
Table 1. Mean length ( $\mathrm{mm})$ of spiny hopsage seedlings in relation to constant and alternating temperatures $\left({ }^{\circ} \mathrm{C}\right.$ ) after 1 week of incubation (source-Dayton, Nev.). ${ }^{a}$

\section{Night}

temperature

\begin{tabular}{l} 
(16 hours) \\
\hline-6 \\
-4 \\
-2 \\
0 \\
2 \\
5 \\
10 \\
15 \\
20 \\
25 \\
30 \\
40
\end{tabular}

Day temperature (8 hours)

\begin{tabular}{lll}
\hline 2 & 5 & 10 \\
0 & 0 & 0 \\
0 & 0 & 0 \\
0 & 0 & $2 k$ \\
0 & $2 \mathrm{k}$ & $2 \mathrm{k}$ \\
$2 \mathrm{k}$ & $2 \mathrm{k}$ & 5 \\
& $5 \mathrm{~g}-\mathrm{k}$ & 5 \\
& & 5 \\
& &
\end{tabular}

Day temperature (8 hours)

${ }_{\text {Means followed by the same letter do not differ significantly at the } 0.01 \text { level of }}$
probability, as determined by Duncan's multiple range test.

\section{Rate of Germination}

Spiny hopsage seeds germinated very rapidly. In rate of germination and juvenile seedling appearance, spiny hopsage is very similar to another member of the Chenopodiaceae, Russian thistle (Salsola iberica) (Young and Evans, 1972).

\section{Seedling Elongation}

Seedlings elongated the most within and $20^{\circ} \mathrm{C}$ for 8 hours daily), $20 / 20$, and $5 / 25^{\circ} \mathrm{C}$ temperatures (Table 1 ). The radicle tip first uncoiled at low temperatures, including -6 alternating with $20^{\circ} \mathrm{C}$. Seedling growth was not greatest at the highest temperature regimes.

\section{Total Germination}

Seed germination at constant temperatures was very similar for seeds from all sources except the Mojave seed, which had a higher germination at 30 and $40^{\circ} \mathrm{C}$ (Table 2). Seeds from the Nevada source failed to germinate at $40^{\circ} \mathrm{C}$. The best germination after 1 week occurred at 10 and $15^{\circ} \mathrm{C}$.

The major influence of the bracts on the seed from California was the reduction in apparent germination at 2 and $5^{\circ} \mathrm{C}$. We say "apparent" germination, because the bracts hid the short radicle elongation at low temperatures.

Optimum germination in relation to alternating temperatures after 2 weeks incubation occurred at a $5^{\circ} \mathrm{C}$ night temperature through a range of 10 to $30^{\circ} \mathrm{C}$ day temperatures (Table 3 ). This germination reflects the ecologic requirement for species in cold-arid environments to germinate late in the fall or early in the spring, while moisture is 1 week at $15 / 20\left(15^{\circ} \mathrm{C}\right.$ for 16 hours available.

\section{Matric Potential}

Germination in the wet cycle was higher on clay-textured soil than on other soils at all but -15 bars. At this point, substrate was no longer strikingly important (Fig. 1). Seeds of spiny hopsage germinated very rapidly, and probably some of the germination observed with the wet cycle in the 15-bar extractor occurred before the soil substrate reached the desired matric potential. Germination was greatly reduced under the dry cycle, especially at matric potentials greater than -4 bars (Fig. 1). The relation between wet and dry cycles indicates that any temporary wetness of the soil may be enough to initiate germination of spiny hopsage.

Germination did not differ markedly in relation to matric potential among seeds of different sources or for threshed vs bracted seeds.

\section{Osmotic Potential}

Seed from Mojave had exceptionally high germination at -12 and -16 bars of osmotic stress created with polyethylene glycol compared to other species reported in the literature of Young et al. (1968) (Fig. 2). Most range grass species have very limited germination at these stress levels. Germination of bracted seeds from Mojave was not reduced significantly $(p=0.01)$ at -8 and -12 bars in comparison with 0 bars. We repeated this experiment three times with similar results. Threshed seeds had reduced
Table 2. Germination (\%) of spiny hopsage seeds in relation to seed source and constant temperatures $\left({ }^{\circ} \mathrm{C}\right)$ af ter 1 week of incubation. ${ }^{a}$

\begin{tabular}{|c|c|c|c|c|c|c|}
\hline \multirow[b]{3}{*}{ Temperature } & \multicolumn{6}{|c|}{ Seed source } \\
\hline & \multicolumn{4}{|c|}{ Nevada } & \multicolumn{2}{|c|}{ California (Mojave) } \\
\hline & Dayton & Medell Flat & Red Rock & Warm Springs & Bracts & No bracts \\
\hline 2 & $8 g$ & $0 h$ & $6 \mathrm{gh}$ & $4 \mathrm{~h}$ & $6 \mathrm{gh}$ & $\mathrm{Oh}$ \\
\hline 5 & $8 \mathrm{~g}$ & $6 \mathrm{gh}$ & $8 g$ & $8 g$ & $4 h$ & $0 \mathrm{~h}$ \\
\hline 10 & $69 b$ & $68 \mathrm{~b}$ & $70 \mathrm{ab}$ & $70 \mathrm{ab}$ & $74 \mathrm{ab}$ & $70 \mathrm{ab}$ \\
\hline 15 & $70 \mathrm{ab}$ & $66 \mathrm{~b}$ & $74 a b$ & $69 b$ & $70 \mathrm{ab}$ & $75 a$ \\
\hline 20 & $43 c$ & $38 \mathrm{~d}$ & $66 \mathrm{~b}$ & $44 c$ & $46 c$ & $44 c$ \\
\hline 25 & $36 d$ & $30 \mathrm{~d}$ & $44 c$ & $30 d$ & $30 \mathrm{~d}$ & $33 d$ \\
\hline 30 & $11 \mathrm{fg}$ & $8 \mathrm{~g}$ & $10 \mathrm{fg}$ & $11 \mathrm{fg}$ & $36 d$ & $32 d$ \\
\hline 40 & $0 \mathrm{~h}$ & $0 \mathrm{~h}$ & $6 \mathrm{gh}$ & $0 \mathrm{~h}$ & $20 \mathrm{e}$ & $15 \mathrm{ef}$ \\
\hline
\end{tabular}

a Means followed by the same letter do not differ significantly at the 0.01 level of probability, as determined by Duncan's multiple range test .

Table 3. Germination (\%) of spiny hopsage seeds in relation to constant and alternating temperatures $\left({ }^{\circ} \mathrm{C}\right)$ after 2 weeks of incubation (source-Dayton, Nev.). ${ }^{a}$

\begin{tabular}{|c|c|c|c|c|c|c|c|c|}
\hline \multirow{2}{*}{$\begin{array}{l}\text { Night } \\
\text { temperature } \\
\text { (16 hours) }\end{array}$} & \multicolumn{8}{|c|}{ Day temperature ( 8 hours) } \\
\hline & 2 & 5 & 10 & 15 & 20 & 25 & 30 & 40 \\
\hline-6 & $0 p$ & $0 p$ & $0 p$ & $0 p$ & $2 p$ & $6 o p$ & $0 p$ & $0 p$ \\
\hline-4 & $0 p$ & $0 p$ & $0 p$ & 10 no & $0 p$ & $20 \mathrm{~m}$ & $25 \mathrm{~m}$ & $6 o p$ \\
\hline-2 & $0 p$ & $0 p$ & 80 & $15 n$ & $25 \mathrm{~m}$ & $28 \mathrm{Lm}$ & $35 \mathrm{~L}$ & $43 k$ \\
\hline 0 & $16 n$ & $45 \mathrm{k}$ & $60 \mathrm{i}$ & $68 g-i$ & $61 \mathrm{hi}$ & $60 \mathrm{i}$ & $52 \mathrm{j}$ & $51 \mathrm{j}$ \\
\hline 2 & $30 \mathrm{~L}$ & $54 \mathrm{j}$ & $76 \mathrm{c}-\mathrm{e}$ & $81 \mathrm{bc}$ & $75 d-f$ & $65 \mathrm{hi}$ & $70 \mathrm{f}-\mathrm{h}$ & $70 \mathrm{f}-\mathrm{h}$ \\
\hline 5 & & $70 f-h$ & $89 a$ & $90 a$ & $85 a b$ & $85 \mathrm{ab}$ & $88 \mathrm{a}$ & $76 c-e$ \\
\hline 10 & & & $77 \mathrm{c}-\mathrm{e}$ & $80 b-d$ & $73 d-f$ & $78 \mathrm{~b}-\mathrm{e}$ & $81 b c$ & $75 \mathrm{~d}-\mathrm{f}$ \\
\hline 15 & & & & $70 \mathrm{f}-\mathrm{h}$ & $53 \mathrm{j}$ & $65 \mathrm{hi}$ & $66 \mathrm{hi}$ & $76 \mathrm{c}-\mathrm{e}$ \\
\hline 20 & & & & & $60 \mathrm{i}$ & $54 \mathrm{j}$ & $72 \mathrm{e}-\mathrm{g}$ & $60 \mathrm{i}$ \\
\hline 25 & & & & & & $42 k$ & $54 j^{\circ}$ & $30 \mathrm{~L}$ \\
\hline 30 & & & & & & & 11 no & $20 \mathrm{~m}$ \\
\hline 40 & & & & & & & & $0 p$ \\
\hline
\end{tabular}

a Means followed by the samc letter do not differ significantly at the 0.01 level of probability, as determined by Duncan's multiple range test. 

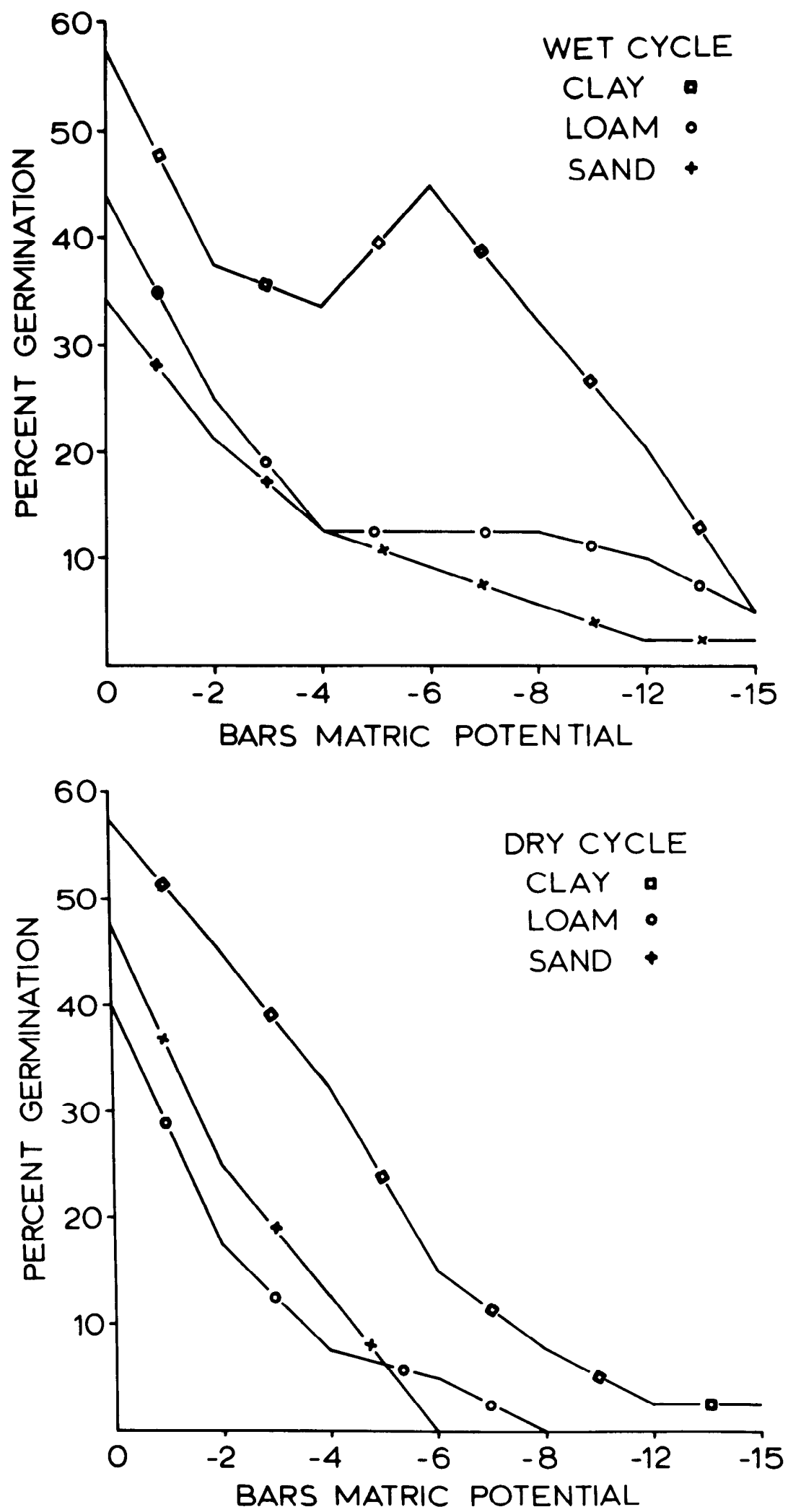

Fig. 1. Germination of seeds of spiny hopsage in relation to matric potential and germination substrate under wet and dry cycles. Seeds threshed from the bracts collected at Dayton, Nev., were used.

germination at -8 and -12 bars compared to 0 or -4 bars. This raises the probability that bracts may help regulate the osmotic potential of germinating seeds. stress was similar to that observed for seeds of most species that have been tested with polyethylene glycol solutions (Young et al., 1968).

When $\mathrm{NaCl}$ was used to create osmotic stress, germination of spiny hopsage ended at -13 bars (Fig. 2). This level probably reflects a salt toxicity rather than osmotic stress.

Soil analysis of spiny hopsage communities in northern Nevada failed to show any surface soils with enough soluble salts to create germination problems for this species (Blackburn et al., 1969). This may not be true for southern California, where the Mojave seed was collected.

\section{Seedling Establishment}

Planting either threshed or bracted seeds $0.5 \mathrm{~cm}$ deep in the soil resulted in the greatest seedling establishment (Table 4). Broadcasting threshed seeds on any soil surface and bracted seeds on smoothed surfaces established few or no seedlings. Bracted seeds broadcast on loose soil resulted in $18 \%$ seedling establishment. This level of establishment may seem low, but very few species that do not have seed mucilage can germinate on the surface of a seedbed without littcr covcrage (Evans and Young, 1972).

\section{Hygroscopic Bracts}

The bracts of spiny hopsage were very hygroscopic. Air-dry bracted seeds increased in weight by $41 \%$ when they were placed in a desiccator over water. When air-dry bracted seeds were placed in a desiccator over $\mathrm{LiCl}$, they lost only $2.5 \%$ weight in 48 hours.

\section{Discussion}

To answer the needs of wildland managers, we must interpret our laboratory experiments in terms of seedbed ecology in the field. We have created

Table 4. Establishment (\%) of spiny hopsage seedlings in relation to scedbed characteristics. $^{\mathrm{a}}$

\begin{tabular}{lcr}
\hline & \multicolumn{2}{c}{ Establishment } \\
\cline { 2 - 3 } Seedbed & $\begin{array}{c}\text { Bracts } \\
\text { entire }\end{array}$ & $\begin{array}{c}\text { Bracts } \\
\text { removed }\end{array}$ \\
\hline On surface & & \\
Loose & $18 \mathrm{~b}$ & $2 \mathrm{~d}$ \\
Smooth & $7 \mathrm{c}$ & $0 \mathrm{~d}$ \\
Packed & $4 \mathrm{~cd}$ & $0 \mathrm{~d}$ \\
Planted $0.5 \mathrm{~cm}$ deep & $51 \mathrm{a}$ & $48 \mathrm{a}$ \\
\hline
\end{tabular}

a Means followed by the same letter do not differ significantly at the 0.01 level of probability, as determined by Duncan's multiple range test. 

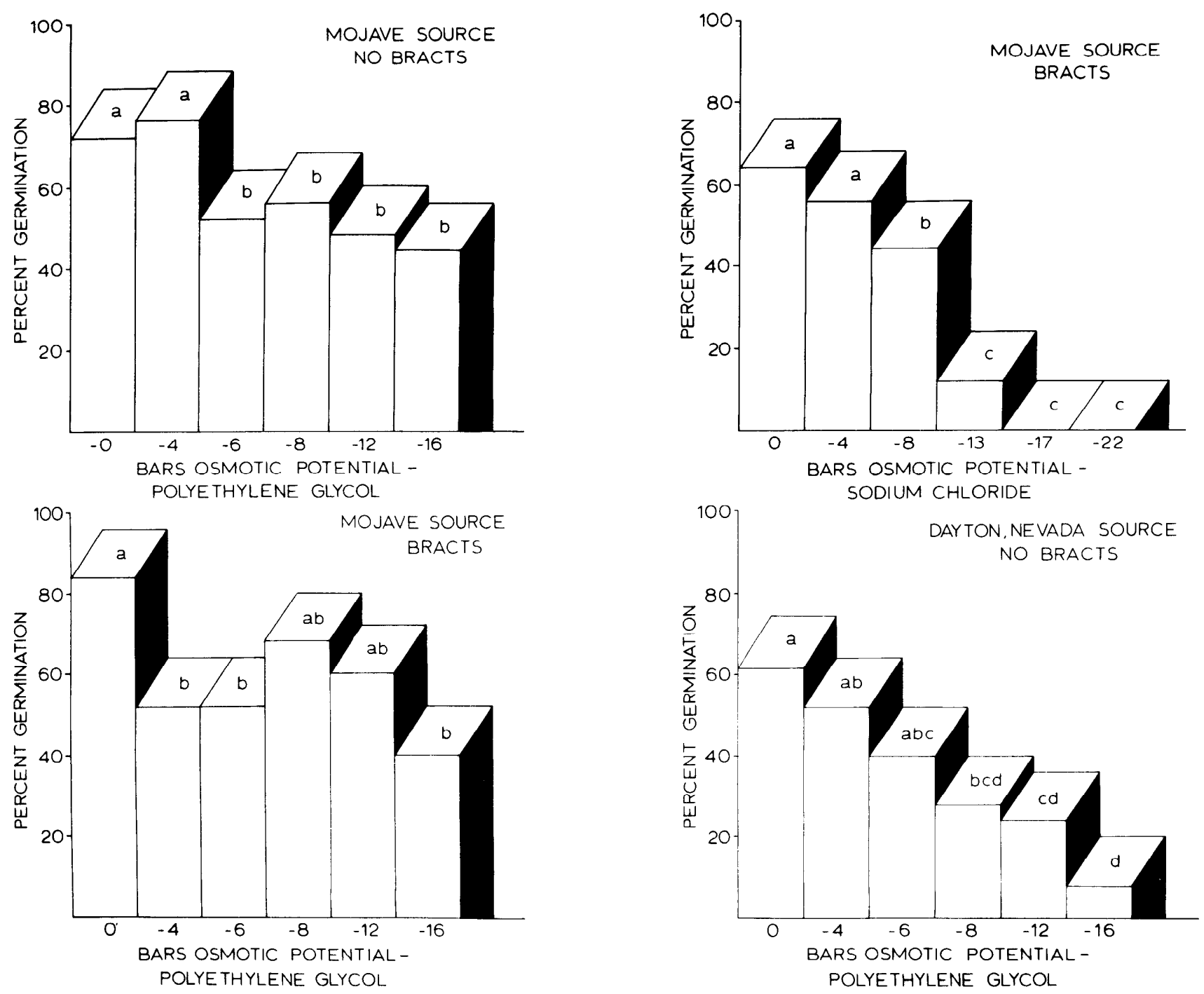

Fig. 2. Germination of seeds of spiny hopsage in relation to osmotic potential created with polyethylene glycol or NaCl solution. Columns topped with the same letter represent means not significantly different at the 0.01 level of probability by Duncan's multiple range test.

some building blocks for a field germination model, but many parameters remain to be established. What happens to bracted spiny hopsage seeds from the time they are mature in midsummer until the first effective fall rain occurs? Do they drop into cracks, or are they otherwise buried? Any land manager who has observed spiny hopsage communities has noted the accumulation of bracts in mini-drifts around micro-obstructions on the soil surface. Do the bracts themselves modify the microenvironment of the seedbed surface and thereby bring moisture within the potential of the seeds to germinate, as has been documented for other cold desert species (Evans and Young, 1970)? The bracts undoubtedly affect germination, as has been noted for the closely related genus Atriplex (Beadle, 1952).

The germination profile in relation to temperature indicates that spiny hopsage is highly adapted to cold seedbeds. Rarely do Intermountain rangelands have warm seedbeds with enough moisture of sufficient duration for germination.

Broadcasting of spiny hopsage seeds for revegetation would be a very risky practice. If it is tried, bracted seeds would have a greater chance for success than threshed seeds.

\section{Literature Cited}

Beadle, N. C. 1952. Studies in Halophytes I. Germination of seed and establishment of seedlings of five species of Atriplex in Australia. Ecology 33:49-62.

Billings, W. D. 1949. The shadscale vegetation zone of Nevada and eastern California in relation to climate and soils. Amer. Midl. Nat. 42:87-109.

Blackburn, W. H., P. T. Tueller, and R. E. Eckert, Jr. 1969. Vegetation and soils of the Churchill Canyon Watershed. Agr. Exp. Sta. Univ. of Nevada, Reno. Bull. R. 45.153 p.

Dayton, W. A. 1931. Important western browse plants. U.S. Dep. Agr. Misc. Pub. $101.213 \mathrm{p}$.

Evans, R. A., and J. A. Young. 1972. Microsite requirements for establishment of annual rangeland weeds. Weed Sci. 20:350-356.

Evans, R. A., and J. A. Young. 1970. Plant litter and establishment of alien annual species in rangeland communities. Weed Sci. 18:697-703.

Springfield, H. W. 1970. Germination and establishment of four-wing saltbrush in the Southwest. Forest Serv., U.S. Dep. Agr. Res. Paper RM-55. 48 p.

Young, J. A., and R. A. Evans. 1972. Germination and establishment of Salsola in relation to seedbed environment. Part I. Temperature, afterripening, and moisture relations of Salsola seeds as determined by laboratory studies. Agron. J. 64:214-218.

Young, J. A., R. A. Evans, and R. E. Eckert, Jr. 1970. Germination characteristics of three species of Cruciferae. Weed Sci. $18: 41-48$.

Young, J. A., R. A. Evans, R. 0. Gifford, and R. E. Eckert, Jr. 1968. Germination of medusahead in response to osmotic stress. Weed Sci. 16:364-368. 